\title{
Intracapsular Enucleation of Intraparotid Facial Nerve Schwannoma with Intratemporal Extension
}

\section{intratemporal Uzanımlı Intraparotid Fasiyal Sinir Schwannomunun intrakapsüler Enükleasyonu}

\author{
(D) Linger SIM1, (D) Xing Yi YEOH², (D) Tay Eng TAN3 , D Zahirrudin ZAKARIA2, (D) Irfan MOHAMAD1
}

\begin{abstract}
'Department of Otorhinolaryngology-Head and Neck Surgery, School of Medical Sciences, Universiti Sains Malaysia Health Campus, Jalan Raja Perempuan Zainab 2, Kelantan, Malaysia

2Department of Otorhinolaryngology-Head and Neck Surgery, Hospital Pulau Pinang, Jalan Residensi, Pulau Pinang, Malaysia

3Department of Pathology, Hospital Pulau Pinang, Jalan Residensi, Pulau Pinang, Malaysia
\end{abstract}

\begin{abstract}
Intraparotid facial nerve schwannoma is a rare condition, which is difficult to preoperatively diagnose without a definite biopsy, yet the diagnosis is important for surgical planning and avoiding accidental injury to the facial nerve. Considering the benign indolent nature of the schwannomas, the management should be prioritized on the long-term tumor control with special attention to the facial nerve function and facial cosmesis. Microscope-assisted intracapsular enucleation is an excellent treatment option for such lesions. Our patient showed House-Brackmann grade II facial function after the surgery. This technique is safe and offers a favorable outcome of facial nerve function.

Keywords: Intracapsular enucleation, intraparotid, facial nerve, schwannoma
\end{abstract}

öz

Intraparotid fasiyal sinir schwannomu, kesin biyopsi olmadan preoperatif olarak teşhis edilmesi zor olan, ancak cerrahi planlama ve fasiyal sinirin kazara yaralanmasını önlemek için teşhis edilmesi önemli olan nadir bir durumdur. Schwannomların benign indolent doğası göz önüne alındığında, fasiyal sinir fonksiyonu ve fasiyal kozmetiklere özel dikkat gösterilerek, uzun süreli tümör kontrolünde yönetime öncelik verilmelidir. Mikroskop destekli intrakapsüler enükleasyon, bu tür lezyonlar için mükemmel bir tedavi seçeneğidir. Hastamız ameliyattan sonra House-Brackmann derece II yüz fonksiyonunu gösterdi. Bu teknik güvenlidir ve olumlu bir fasiyal sinir fonksiyonu sonucunu sunar. Anahtar kelimeler: İntrakapsüler enükleasyon, intraparotid, fasiyal sinir, schwannoma

\section{INTRODUCTION}

Schwannomas are ectodermal benign tumors that arise from the Schwann cells that unsheathe the nerve axons. Facial nerve schwannomas, with a low reported prevalence of $0.15-0.8 \%$ can occur anywhere along the course of the facial nerve from the cerebellopontine angle to the facial terminal branches'. Most of these tumors are intratemporal and intracranial, with only $9 \%$ extratemporal segment involvement. The pre-operative diagnosis of facial nerve schwannomas is difficult due to their insufficient associated distinctive features.
Furthermore, the management in patients with normal or favorable facial nerve function remains a challenge as inadvertent injury to the facial nerve may occur during the surgery ${ }^{2}$.

\section{CASE REPORT}

A 47-year-old female patient presented with a right infra-auricular swelling for 4 years. It progressively increased in size and was associated with intermittent right facial pain for the past 1 year. Additionally, facial asymmetry or numbness and otological symptoms were not noted. 
The physical examination showed a single $3 \times 3 \mathrm{~cm}$ firm, mobile, and non-tender mass over the right infraauricular area, without palpable neck nodes. The patient had no trismus. Flexible nasopharygolaryngoscopy showed no medialization of the lateral pharyngeal wall. The facial nerve function was normal.

Contrast-enhanced computed tomography (CECT) of the neck revealed a well-defined enhancing mass, measuring $1.9 \times 2.9 \times 3.4 \mathrm{~cm}$, involving both superficial and deep lobes of the right parotid gland with proximity to the right stylomastoid foramen (Figure 1). Gadoliniumenhanced brain and neck magnetic resonance imaging (MRI) showed an isointense lesion on $\mathrm{Tl}$ and hyperintense on T2 images with small cystic changes. The lesion appeared to be in continuity proximally into the stylomastoid foramen with a slight expansion of the mastoid segment of the right facial nerve (Figure 2).

The ultrasound-guided core needle biopsy of the mass showed numerous spindle-shaped cells that are arranged in palisade architecture, likely Antoni
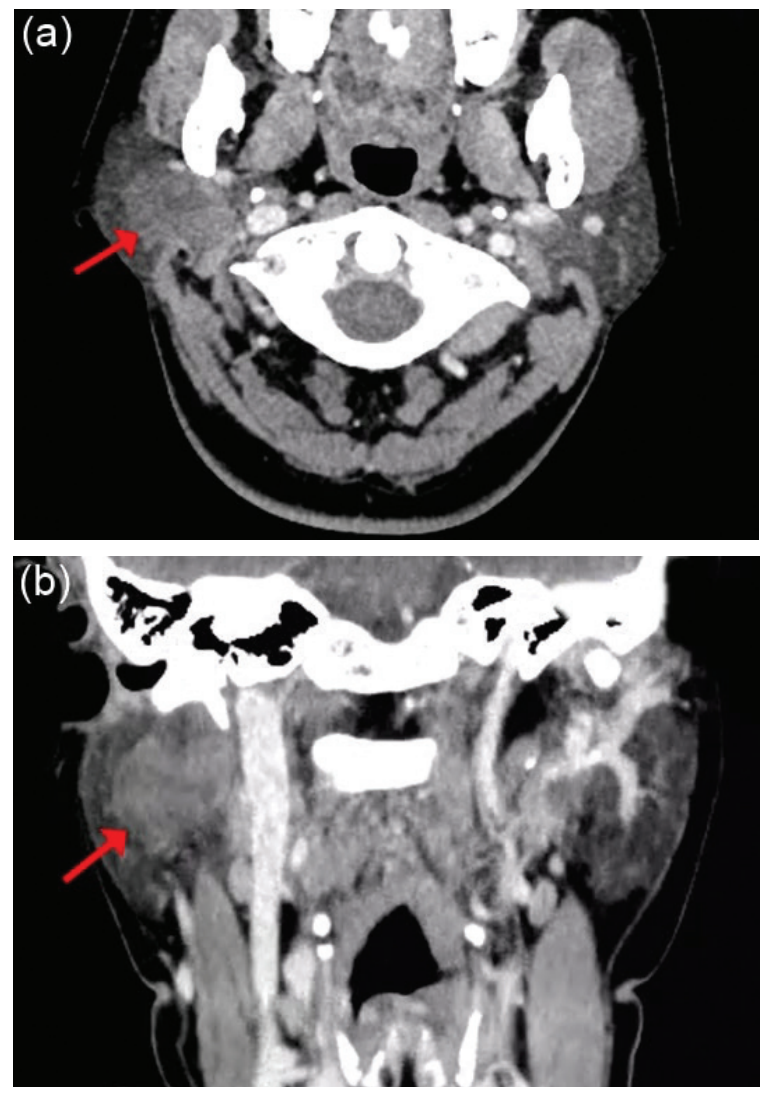

Figure 1. Contrast-enhanced computed tomography neck showing enhancing mass involving the superficial and deep lobes of the right parotid gland near the stylomastoid foramen; a. Axial view; b. Coronal view. type A areas or Verocay bodies, suggesting a possible schwannoma. With the above findings, a provisional diagnosis of an intraparotid facial nerve schwannoma with intratemporal extension was entertained. The patient subsequently underwent intracapsular facial nerve schwannoma enucleation via a combined transmastoid and parotidectomy approach.

The surgery was performed by making a postauricular Fisch type A skin incision. After raising the superficial muscular aponeurotic system and the subplatysmal layer
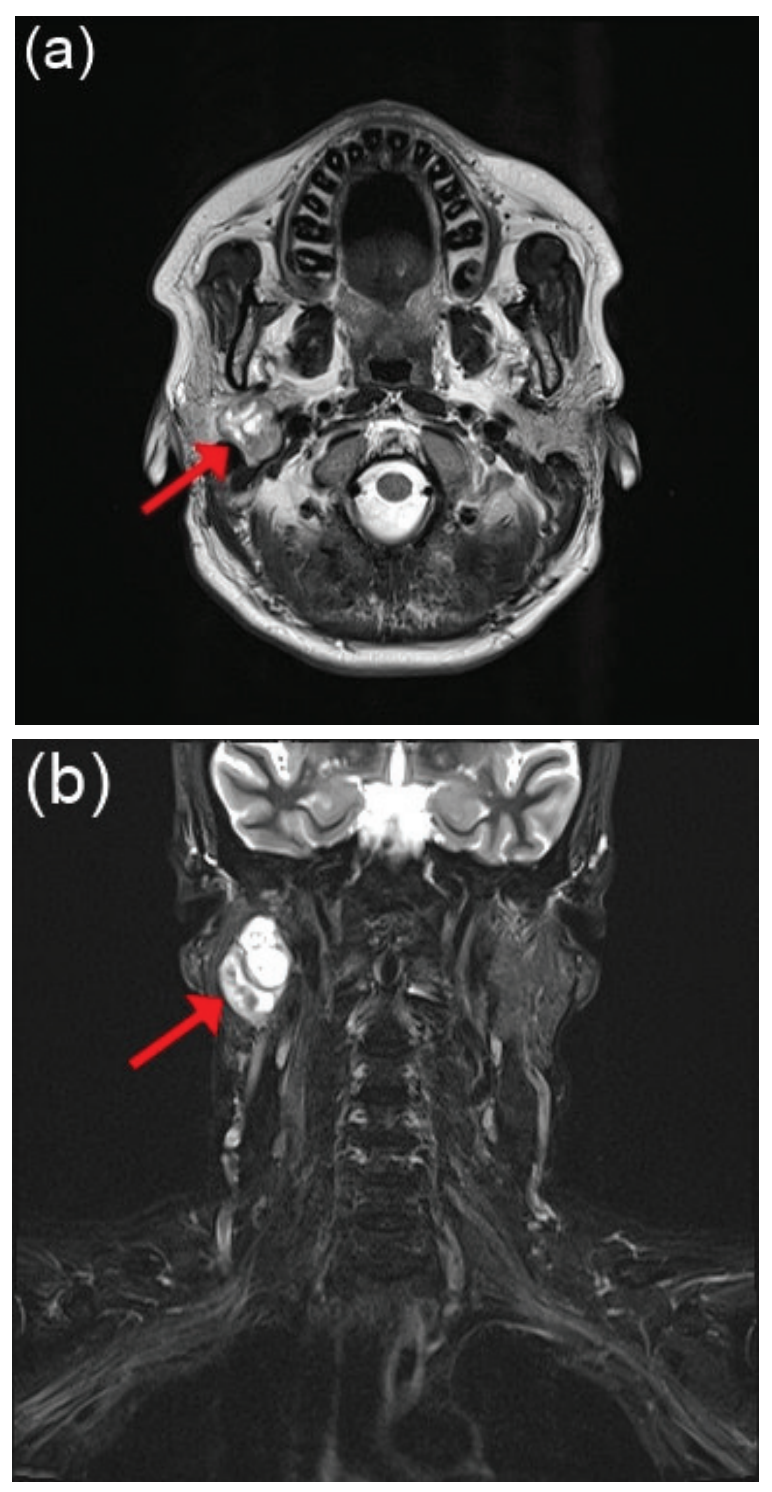

Figure 2. T2-weighted magnetic resonance imaging showing heterogeneously enhancing mass with center cystic changes at the right parotid gland; a. Axial view; b. Coronal view. 
the main trunk of the right facial nerve was retrogradely traced using the right marginal mandibular and cervical nerve (Figure 3). The right great auricular nerve was identified and preserved, particularly for possible facial nerve reconstruction. The tumor was found to arise from the main trunk, pes anserinus, and proximally extended to the stylomastoid foramen and the distal segment of the vertical or mastoid segment of the facial nerve (Figure 4a). Cortical mastoidectomy was performed to identify the facial nerve at the second genu, and the nerve was distally traced until the tumor at the mastoid segment. The digastric ridge was identified and the mastoid tip was transected (Figure 4b). Intracapsular enucleation of the tumour was conducted under the microscope. An incision was carefully made in the epineurium (tumor capsule) and was retracted away from the tumor surface. The plane of the tumor surface was gently and meticulously dissected, stripping the tumor off the underlying nerve fascicles. The tumor was removed en-bloc, measuring $8 \times 2 \mathrm{~cm}$ in total (Figure 5a, b). The right facial nerve was identified and preserved.

Postoperatively, the patient developed right facial nerve palsy House-Brackmann (HB) grade II that persisted for 7 months during her last visit to the clinic. The histopathological examination of the tumor was consistent with schwannoma, which showed Antoni A and $B$ cell patterns and the presence of Verocay bodies (Figure 6a, b).

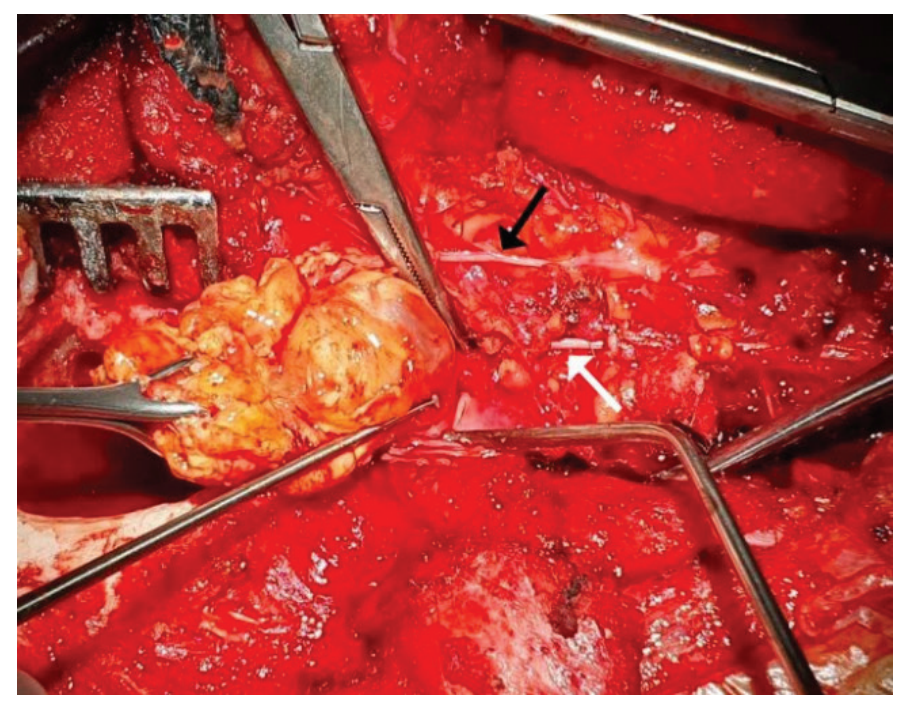

Figure 3. Cervical and marginal mandibular nerve used in retrograde dissection to identify the main trunk of the facial nerve.

Black arrow: Marginal mandibular nerve, White arrow: Cervical branch
Written informed consent was obtained from the patient to be published in this article.

\section{DISCUSSION}

Intraparotid facial nerve schwannomas most commonly present as slow-growing painless parotid masses that mimic the presentation of other primary parotid neoplasms. Facial nerve palsy is uncommon and would raise the suspicion of the malignant counterpart if it occurs. Otological symptoms, such as tinnitus, hearing loss, or imbalance, may occur in the presence of intratemporal extension ${ }^{3}$. Our patient presented with a parotid mass, which was clinically indistinguishable from the parotid tumor. Fortunately, the result of the ensuing investigations pointed toward facial nerve schwannoma, which is often not the case. Most tumors are only intraoperatively noticed and posed a dilemma to the treating surgeon ${ }^{4}$.
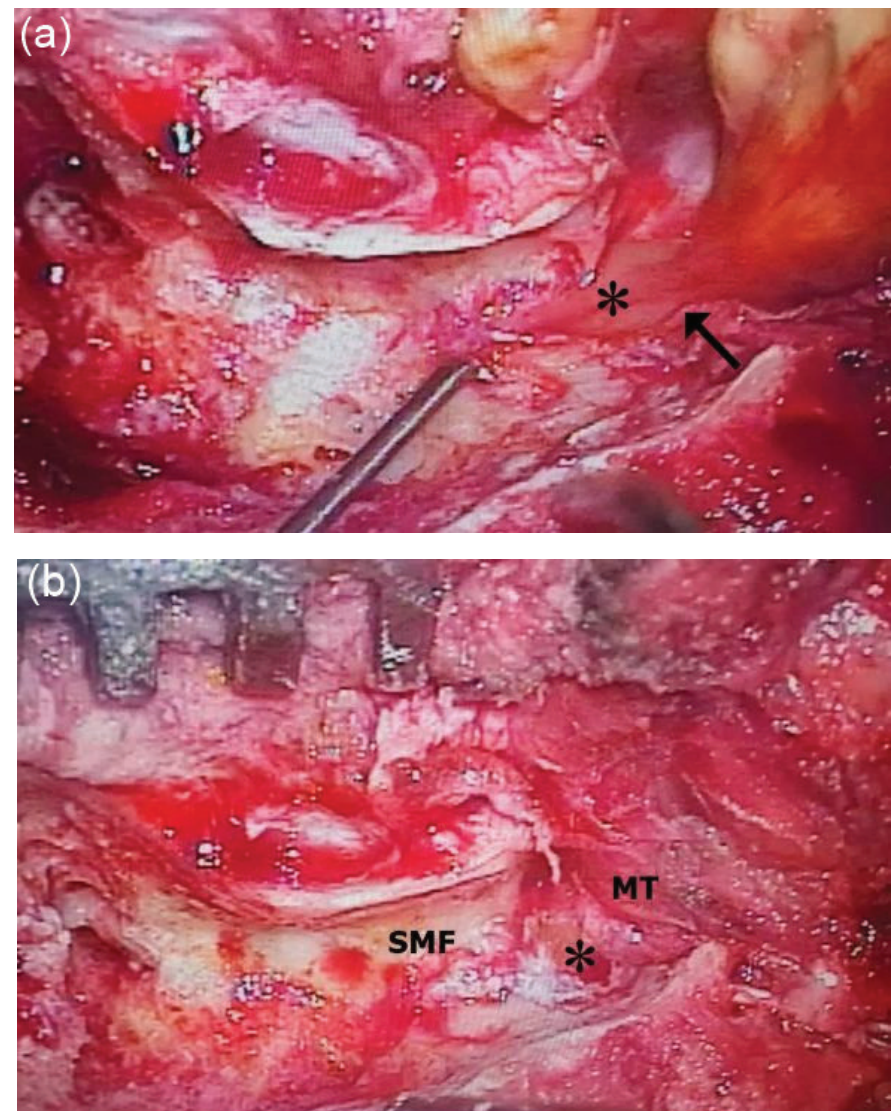

Figure 4. Intratemporal extension; a. Tumor extending to the mastoid segment of the right facial nerve (Arrow: Stylomastoid foramen); b. Transected mastoid tip.

MT: Mastoid tip, Asterisk: Mastoid segment, SMF: Stylomastoid foramen 

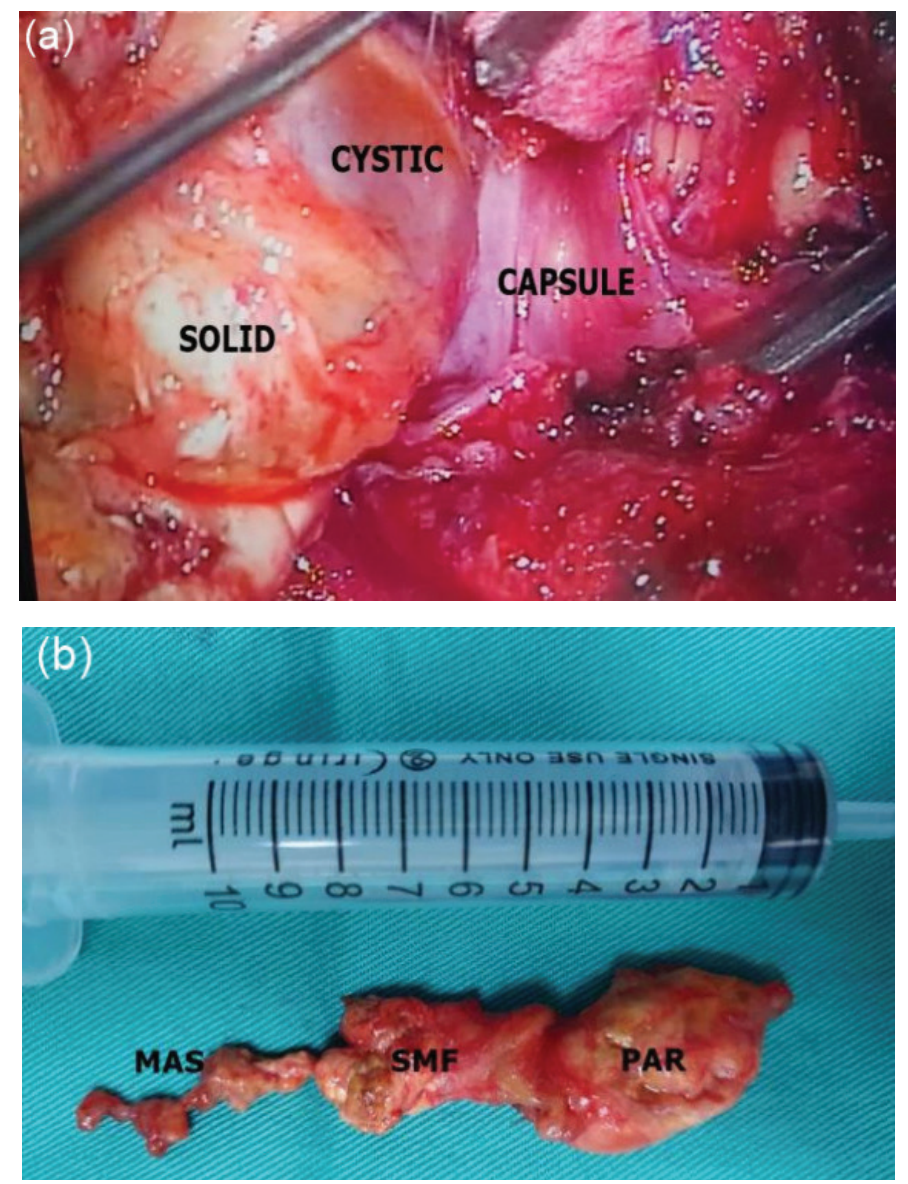

Figure 5. Intracapsular enucleation; a. Solid-cystic tumor component and dissection of tumour capsule away from the tumor surface; $b$. Tumor removed en-bloc.

MAS: Mastoid segment, SMF: Stylomastoid foramen segment, PAR: Parotid segment

Facial nerve schwannoma in CT scan usually presents as a round circumscribed, enhancing soft tissue mass. Whereas, MRI, as the preferred imaging modality, shows mildly hypo- or isointense $\mathrm{Tl}$ and heterogeneously hyperintense T2-weighted images. However, these imaging findings are similar to pleomorphic adenoma, hemangioma, benign lymphoepithelial lesions, and acinic cell carcinoma. Moreover, findings, such as cystic features and extension into stylomastoid foramen or facial canal" instead of as shown in our case, may suggest but are not diagnosis-specific. These findings are also seen in parotid malignancies with perineural spread and albeit rarely, pleomorphic adenoma 5 .

Fine needle aspiration cytology (FNAC) is a safe and simple method for parotid mass evaluations. Microscopic appearances of schwannomas are shown as either Antoni A with spindle cells that are arranged
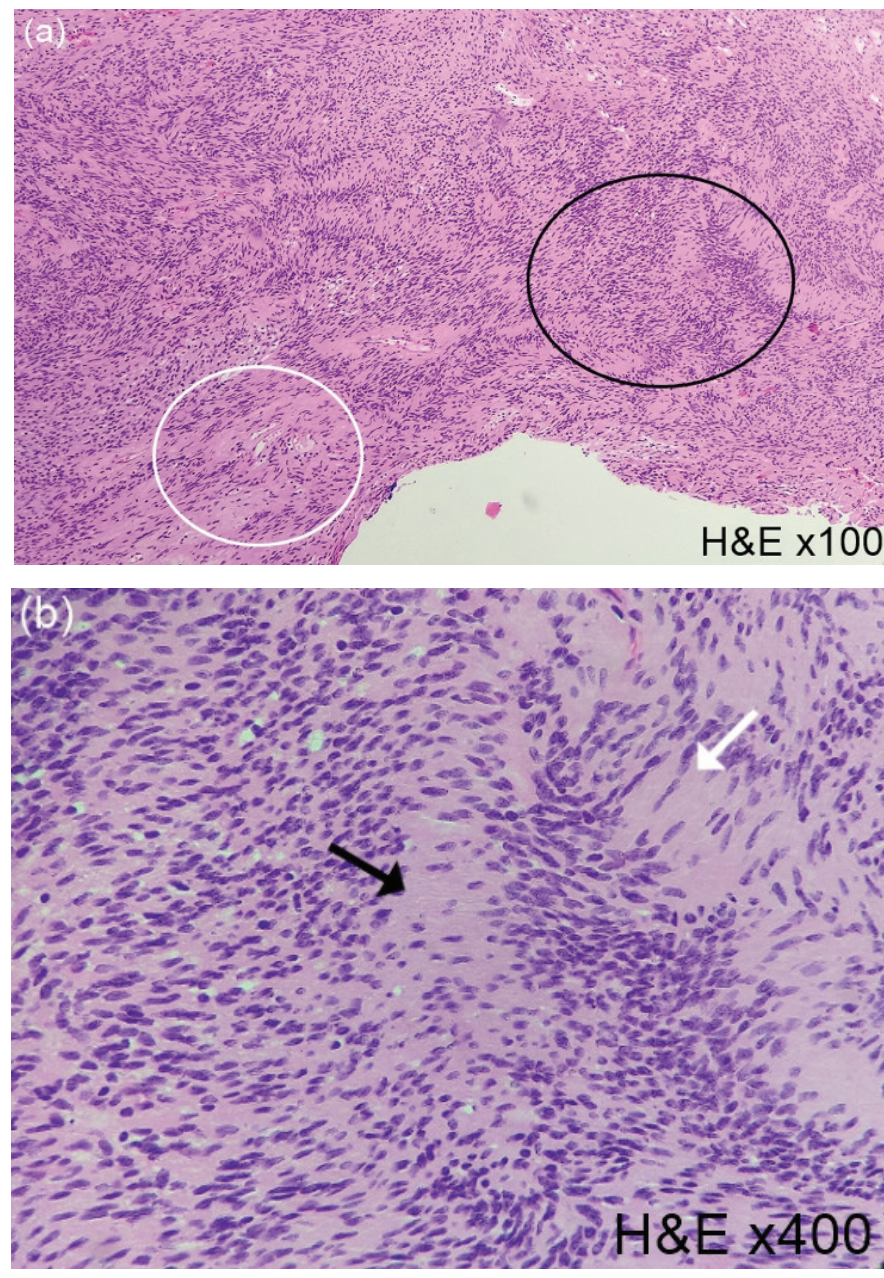

Figure 6. Histopathological findings; a. Antoni A with of dense cellular spindle cells and Antoni B with loose hypocellular feature (black circle: Antoni A; white circle: Antoni B); b. Verocay bodies, eosinophilic fibrillary processes between rows of palisading cells (black arrow: Verocay bodies, white arrow: cells with nuclear palisading).

in fascicles or Antoni B with lower cellular density in a reticular pattern. The presence of the Verocay bodies is the characteristic feature. However, the FNAC accuracy in diagnosing facial nerve schwannomas was only 22-33\%, probably due to failure of detection of Verocay body and the typical pattern of spindle cells. The result often turns out inconclusive or at times as pleomorphic adenomas. This might lead to pre-operative misdiagnosis, which is not uncommon. Thus, the diagnosis can only be intraoperatively clinched during a parotidectomy, when the facial nerve cannot be located or the nerve is found entering the tumor. By then, the facial nerve might have been inadvertently injured ${ }^{6}$. A biopsy is undoubtingly the way to confirm the diagnosis. We advocate the use of 
ultrasound guidance to accurately detect the desirable sampling site. It is a safe and efficient procedure with an accuracy rate as high as $97 \%$ in diagnosing parotid masses, obviating the need for intra-operative frozen sections ${ }^{7}$.

This case posed a high index for suspicion of schwannoma as the serial imaging showed tumor enlargement along with the anatomic nerve location, from an initial parotid tumor at the facial nerve trunk area, and through the years, extending proximally to the mastoid portion of the facial nerve. Fitting to her presentation of an initially painless parotid mass, she developed pain when the tumor intratemporally extended as it was enlarging in a bony confine, which prompted her to pursue surgical intervention. The cause of pain is unknown but is likely related to nerve compression from the tumor growth within the fallopian canal limitation compared to the parotid gland's ability to accommodate the tumor expansion ${ }^{8}$.

Facial nerve schwannoma management varies from tumor resection with reconstruction to facial nerve preservation surgery, such as decompression, radiosurgery, stripping surgery, and intracapsular enucleation. The management remains controversial with insufficient good evidence to support any particular treatment algorithm due to the rarity and heterogeneity of the disease and difficulty in conducting prospective trials. Generally, an evolving philosophy toward a more conservative approach appeared to preserve the facial nerve function for as long as possible?

This is contrary to the previously shared idea that facial nerve schwannomas should be excised and grafted ${ }^{9}$. To date, no facial nerve reconstruction method has achieved better recovery than HB grade III. Whereas, stripping surgery varies in facial nerve preservation ranging from $25 \%$ to $70.6 \%$. By comparison, intracapsular enucleation appears as a more reliable technique with promising facial nerve outcomes, and most patients recovered to HB grades I or $\mathrm{II}^{10}$. Our patient had a preoperatively normal facial nerve function, which led to the reluctance of both the patient and the surgeon to surgically intervene due to the morbidity. Postoperatively, our patient had an HB grade II palsy, which is in concordance with other studies. Tumor capsule removal was unnecessary as it is not associated with tumor recurrence ${ }^{10,11}$.

The surgical approach for tumor removal is dictated by the tumor location, hearing levels, and surgeon preference. This patient had mastoid and parotid segments involvement; therefore, a transmastoid and parotidectomy approach was employed. Fisch type A skin incision was chosen for our patient, which allowed access to both areas. The tumor was identified via the retrograde identification of the marginal mandibular nerve that was proximally traced leading to the tumor and by a cortical mastoidectomy to identify the second genu, distally tracing it toward the distal mastoid segment where the tumor was located. Exposing both proximal and distal segments of the normal parts of the nerve is imperative to properly dissect and enucleate the tumor. This approach rendered a favorable facial nerve outcome for the patient without recurrence to date.

Pre-operative diagnosis of intraparotid facial nerve schwannomas is exceptionally challenging. In cases where the diagnosis is established, intracapsular enucleation under microscope guidance is an excellent treatment option. This technique is safe and offers a favorable facial nerve outcome.

\section{Ethics}

Informed Consent: Written informed consent was obtained from the patient to be published in this article.

Peer-review: Externally and internally peerreviewed.

\section{Author Contributions}

Surgical and Medical Practices: X.Y.Y., Z.Z., Concept: X.Y.Y., I.M., Literature Search: L.S., Writing: L.S., T.E.T., I.M.

Conflict of Interest: The authors declare that they have no conflict of interest.

Financial Disclosure: The authors declared that this study has received no financial support.

\section{REFERENCES}

1. Chung JW, Ahn JH, Kim JH, Nam SY, Kim CJ, Lee KS. Facial nerve schwannomas: different manifestations and outcomes. Surg Neurol. 2004:62:245-52.

2. Gross BC, Carlson ML, Moore EJ, Driscoll CL, Olsen KD. The intraparotid facial nerve schwannoma: a diagnostic and management conundrum. Am J Otolaryngol. 2012;33:497-504.

3. Fyrmpas G, Konstantinidis I, Hatzibougias D, Vital V, Constantinidis J. Intraparotid facial nerve schwannoma: management options. Eur Arch Otorhinolaryngol. 2008;265:699-703.

4. Ma Q Song H, Zhang P, Hou R, Cheng X, Lei D. Diagnosis and management of intraparotid facial nerve schwannoma. J Craniomaxillofac Surg. 2010;38:271-3.

5. Mundada P, Purohit BS, Kumar TS, Tan TY. Imaging of facial nerve schwannoma: diagnostic pearls and potential pitfalls. Diagn Interv Radiol. 2016:22:40-6.

6. Li S, Lu X, Xie S, Li Z, Shan X, Cai Z. Intraparotid facial nerve schwannoma: a 17-year, single-institution experience of diagnosis and management. Acta Otolaryngl. 2019;139:444-50. 
7. Wan YL, Chan SC, Chen YL, et al. Ultrasonography-guided coreneedle biopsy of parotid gland masses. AJNR Am J Neuroradiol. 2004;25:1608-12.

8. Bartindale M, Heiferman J, Joyce C, Balasubramanian N, Anderson $D$, Leonetti J. The natural history of facial nerve schwannomas: a meta-analysis of case series. J Neurol Surg B Skull Base. 2019:80:458-68.

9. Watkinson JC, Clarke RW. Scott-Brown's otorhinolaryngology and head and neck surgery: paediatrics, the ear, and skull base surgery. $8^{\text {th }}$ ed. CRC Press; 2018.
10. Zheng Z, Li J, Shen Y, Xu L, Sun J. Radical intracapsular microenucleation technique for exclusively intraparotid facial nerve schwannoma: long-term follow-up review. J Craniomaxillofac Surg. 2016;4:1963-9.

11. Rigante M, Petrelli L, DE Corso E, Paludetti G. Intracapsular microenucleation technique in a case of intaparotid facial nerve schwannoma. Technical notes for a conservative approach. Acta Otorhinolaryngol Ital. 2015;35:49-52. 